\title{
ÜLŐBÚTOR TESZTELŐ BERENDEZÉS TERVEZÉSE
}

\author{
Barna Bence \\ hallgató, Miskolci Egyetem \\ Gép- és Terméktervezési Intézet \\ 3515 Miskolc, Miskolc-Egyetemváros, e-mail: bncb095@gmail.com \\ Takács Ágnes \\ egyetemi docens, Miskolci Egyetem \\ Gép- és Terméktervezési Intézet \\ 3515 Miskolc, Miskolc-Egyetemváros, e-mail: takacs.agnes@uni-miskolc.hu
}

\begin{abstract}
Absztrakt:
A bútoriparban nagy hangsúlyt fektetnek az ülöbútorok kényelmére. A kényelem növelésének érdekében új kialakitásokat és anyagokat vezetnek be az ülöbútorok gyártásánál. Egy új ülöbútor mielött a gyártótól eljut a vásárlóig többlépcsös tesztelési folyamaton esik át. Az egyik folyamat az ülöbútorok terhelés beviteles tesztelése. A cél egy olyan tesztelö berendezés tervezése, amely ebben a tesztelési szakaszban egyszerüen és hatékonyan alkalmazható a tesztelés elvégzésére. A cikk ezen ülőbútor tesztelö berendezés tervezésének néhány lépését foglalja össze.
\end{abstract}

Kulcsszavak: tervezés, bútortesztelö berendezés, pneumatika

\section{Abstract:}

In the furniture industry, great attention is placed on the comfort of seat furniture. In order to increase comfort new constructions and materials are introduced in the production of seat furniture. A new seat furniture before it gets to the customer goes through a multi-step testing process. One of the processes is the durability testing. The aim is to design a testing device that can be used simply and effectively for testing in this phase of furniture design. This paper summarizes some steps of designing this seat furniture testing equipment.

Keywords: design, seat furniture testing device, pneumatics

\section{Bevezetés}

A nagy bútoripari vállalatok az általuk gyártott termékre vonatkozóan komoly minőségbiztosítási rendszert alakítottak ki. Ennek oka: a fogyasztók bútoripari termékekkel szemben támasztott egyre magasabb elvárásai (pl.: tartósság, kényelem, ergonomikus kialakítás).

A termékek minőségének biztosítását több részre lehet osztani, ezek közül néhány fontosabb tényezö:

- a gyártóberendezések megfelelő állapota, a minőségi gyártás érdekében,

- minőségi alapanyagokból való gyártás,

- komfortellenörzési tesztek,

- minőségellenőrzési tesztek végzése, célberendezéseken.

A tervezési feladat témája egy olyan berendezés tervezése, amely a minőségellenőrzési tesztek elvégzése közül az ülő, illetve hátfelület elemek teherbírásának tesztelésére alkalmas (pl.: a rugózat és 
a szivacsos elemek ellenállásának, tartósságának elemzése a terhelésekből származó deformációk szempontjából).

A megoldásváltozatok részben saját ötletek, valamint a www.espacenet.com és a www.google.hu/PATENTS oldalakon végzett szabadalomkutatás, illetve piackutatás során feltárt megoldások alapján kerültek megfogalmazásra. A kutatás eredménye szerint szabadalom véd számos, különböző komplett bútortesztelő berendezést és a berendezéshez tartozó részegységeket is. A piackutatás során kereskedelmi forgalomban kapható berendezést nem lehetett fellelni, a kereskedelemben csak a berendezés megépítéséhez szükséges részegységek szerezhetők be.

A koncepcionális tervezés során számos lehetséges megoldásváltozat közül Copeland módszer segítségével került kiválasztásra az a változat, amely az értékeléshez megfogalmazott szempontoknak a leginkább megfelelt. [6,7] Az értékelés segítségével kiválasztott változat révén egy egyszerüen, biztonságosan üzemeltethető és karbantartható ülöbútor tesztelő berendezés valósítható meg. Az előzetes tervek alapján elkészült ennek a változatnak a 3D-s modellje, amelyet az 1. ábra szemléltet. [3] A tervezés további lépéseiben mérnöki számításokra és a berendezés működésének megtervezésére került sor. $[1,2,5]$

\section{A berendezés felépítése}

Az 1. ábra a tervezés során elkészült ülöbútor tesztelö berendezés 3D-s modelljét mutatja be. A vázszerkezetet Iramko MK 10 100x100 nagyteherbírású alumínium profilok alkotják, amelyek sarokelemekkel vannak egymáshoz csatlakoztatva. [9]

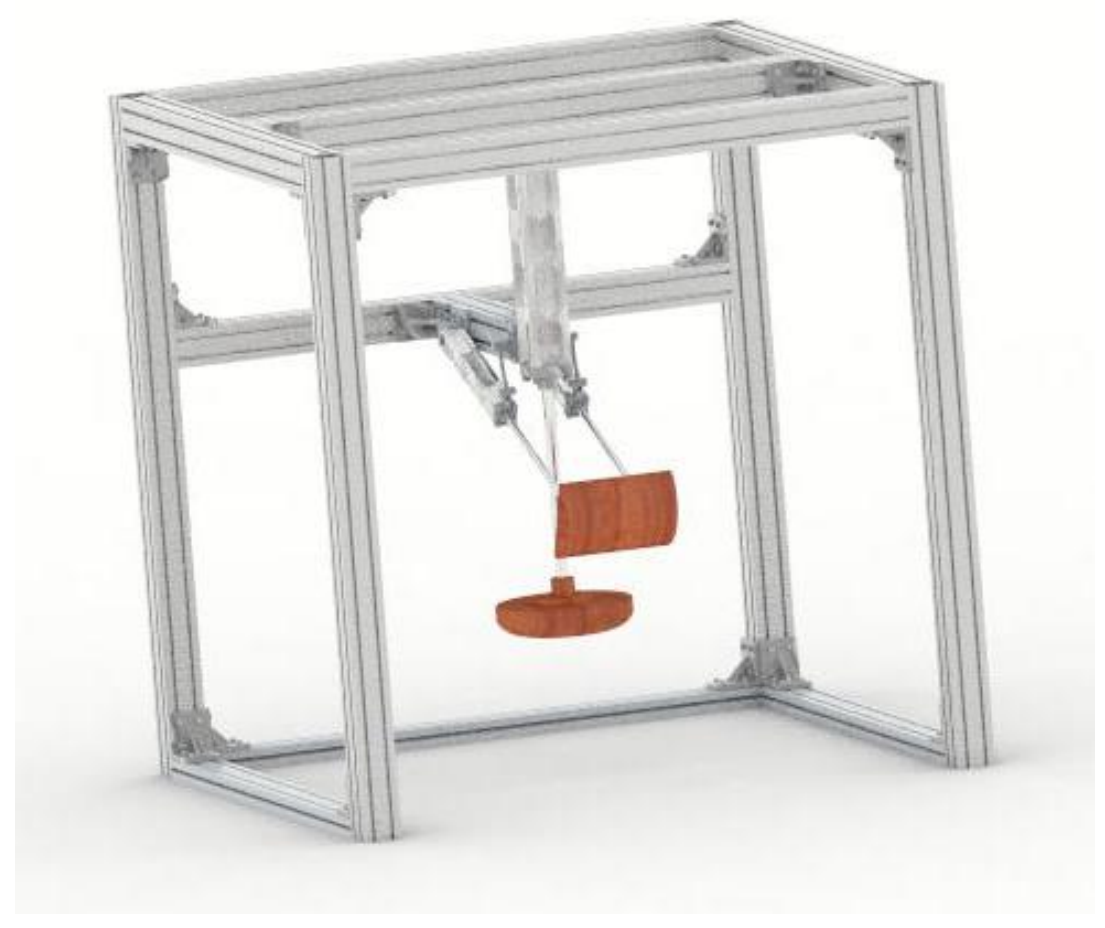

1. ábra: Az ülöbútor tesztelö berendezés $3 D$ modellje 
A vázon két tartó van elhelyezve, amelyhez a terhelést végző pneumatikus munkahengerek csatlakoznak. A berendezésben található egy függőleges elrendezésű munkahenger, ami az ülőfelület terhelését végzi és egy vízszintes munkahenger pár, amelyek egymással párhuzamosan müködnek, ezek végzik a támlafelület terhelését. A munkahengerek dugattyú rúdjainak végei terhelőfejekkel vannak ellátva, amelyek az egyenletesebb erőelosztást biztosítják.

\section{A berendezés müködési leírása}

A berendezésben használt munkahengerek és út szelepek [4]:

Munkahengerek:

- függőleges munkahenger: FESTO DSBC kettősmüködésủ szabványon alapuló dugattyúrudas munkahenger

- vízszintes munkahenger: FESTO DSBC kettősmüködésű szabványon alapuló dugattyúrudas munkahenger

Útszelepek:

- FESTO VTUB-12; 5/2 elektromos vezérlésü, elővezérelt bistabil útszelep

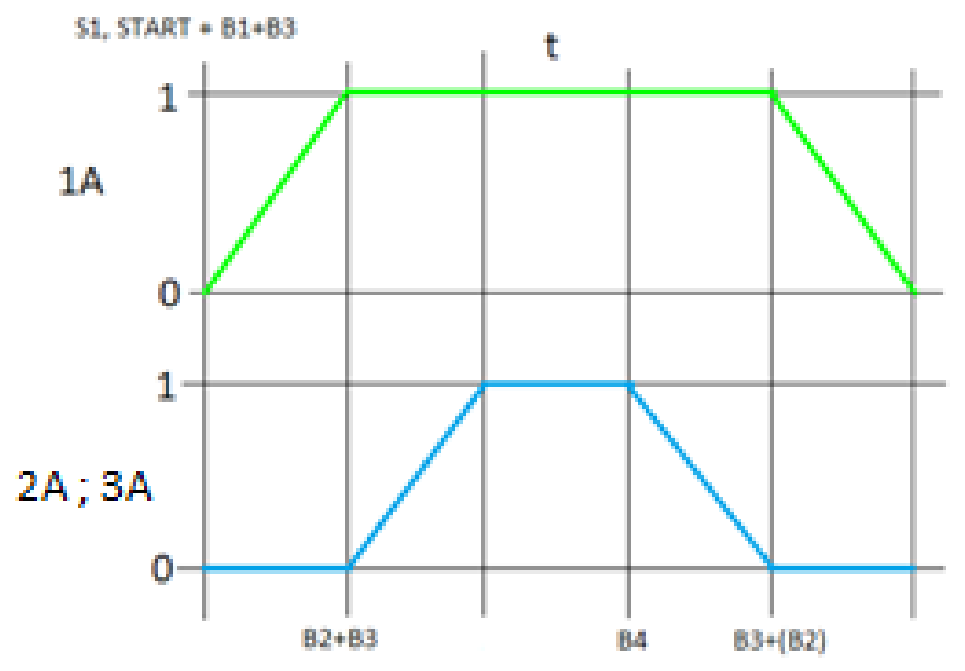

2. ábra: A munkahengerek ütemdiagramja

A munkahengereket elektromos vezérlésü, elővezérelt bistabil útszelepek müködtetik. A 2A és a $3 \mathrm{~A}$ jelü munkahenger egymással párhuzamosan van kapcsolva. A dugattyú helyzetét a B1, B2, B3, B4 jelü Reed-relék érzékelik. A munkahengerek vezérlése háromutas kapcsolással van megvalósítva. A háromutas kapcsolást a 3. ábra szemlélteti.

Ha mindkét munkahenger alaphelyzetben van, tehát B1 és B3 Reed-relék érzékelnek, az S1 jelü billenő kapcsoló lenyomásával megkezdődik a munkaciklus. Miután az 1A jelü munkahenger kimegy, a B2 és B3 jelü Reed- relék érzékelnek. Ezek hatására kifut a 2A-3A jelü munkahenger, a B4 jelü Reed-relé érzékel, melynek hatására a K3 bekapcsolásra késleltetett időzítő relé elkezd 
visszaszámolni, majd t idő múlva behúz. Ennek hatására a 2A-3A jelü munkahenger visszafut alaphelyzetbe, érzékel a B3 Reed-relé, majd az 1A jelü munkahenger is visszafut kiinduló helyzetébe. Az egész folyamat kezdődik előröl. A ciklus addig ismétlődik, amíg az S1 billenő kapcsoló bekapcsolt állapotban van, vagy nem aktiválják a vészstoppot. Az útváltó szelepeket közvetetten vezéreljük relék segítségével.

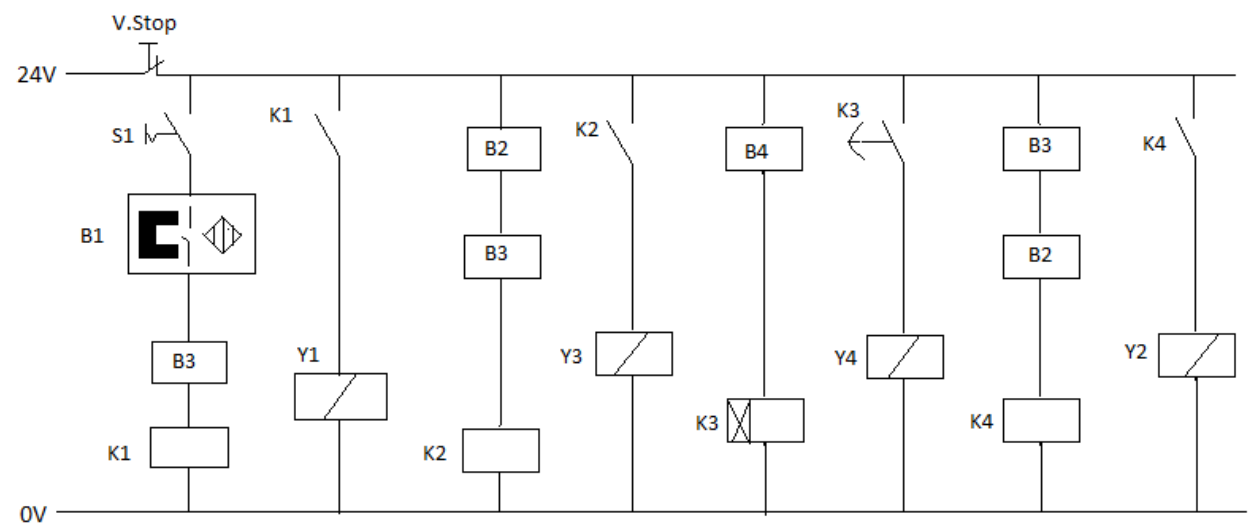

3. ábra: A munkahengerek vezérlése

\section{4. Összefoglalás}

A koncepcionális tervezés során a szabadalomkutatást követően a funkcióanalízis révén feltárt funkciókat felhasználva megoldásváltozatok kerültek megfogalmazásra. A megoldásváltozatok Copeland eljárás segítségével kerültek kiértékelésre, így az értékelési szempontoknak leginkább megfelelő megoldásváltozat került kiválasztásra. Ezután a további tervezési feladatok elvégzésére került sor. A szükséges számítások és tervezési lépések elvégzése után elkészült a berendezés 3D modellje Solid Edge ST9 program használatával.

A megtervezett ülőbútor tesztelő berendezés alkalmas különféle székek, és fotelek gyors és hatékony tesztelésére, mivel a berendezés a tesztelés során két feladatot lát el: az ülő és támla felület tesztelését egyetlen munkaciklusban. A jövőben azonban el kell még végezni a berendezés véges elemes analízisét, hogy ezáltal a szerkezet gyenge pontjai meghatározhatók legyenek. [8]

A berendezés továbbfejlesztése is egy távlati cél, amely során egy hasonló müködési elvvel és egy újabb konstrukcióval rendelkező szerkezet különböző típusú ülő, illetve fekvő bútorok tesztelésére lenne alkalmas.

\section{Köszönetnyilvánítás}

A cikkben ismertetett kutató munka az EFOP-3.6.1-16-2016-00011 jelü „Fiatalodó és Megújuló Egyetem - Innovatív Tudásváros - a Miskolci Egyetem intelligens szakosodást szolgáló intézményi fejlesztése" projekt részeként - a Széchenyi 2020 keretében - az Európai Unió támogatásával, az Európai Szociális Alap társfinanszírozásával valósul meg. 


\section{Felhasznált irodalom}

[1] Zsáry, Á.: Gépelemek I., Nemzeti Tankönyvkiadó, Budapest, 1989, ISBN: 9631945855

[2] Zsáry, Á.: Gépelemek II., Nemzeti Tankönyvkiadó, Budapest, 1991, ISBN: 96318 6443X

[3] Herczeg, I.: Szerkesztési atlasz, Müszaki Könyvkiadó, Budapest, 1976, ISBN: 9631007901

[4] FESTO Bevezetés a pneumatikába (P111)

[5] Péter, J.: A géptervezés alapjai, Miskolci Egyetemi Kiadó, 2017, ISBN:978 9636618377

[6] Takács, Á.: Computer Aided Concept Building, Solid State Phenomena 261, 2017, pp.402-407, https://doi.org/10.4028/www.scientific.net/SSP.261.402

[7] Takács, Á., Kamondi, L.: On Design Theories: Fundamentals of a Neuvel Approach, Advanced Engineering 5 Vol.1, 2011, pp. 109-118.

[8] Szabó, F. J.: Optimization possibilities and methods in product development and qualification, Design of Machines and Structures, 1 Vol 2, 2012. ISSN: 1785-6892

[9] MK Technology Group: Profile Technology katalógus 